\title{
Rat Liver Adenyl Cyclase Activity in Various Thyroid States
}

\author{
Judith K. Jones, Faramarz Ismail-Beigi, and Isidore S. Edelman \\ From the Cardiovascular Research Institute, and the Departments of Medicine, \\ and of Biochemistry and Biophysics of the University of California School of \\ Medicine, San Francisco, California 94122
}

\begin{abstract}
A B S T RACT Thyroidectomized and euthyroid rats were injected with three doses of triiodothyronine $\left(\mathrm{T}_{3}\right)$ or of the diluent over a 6 day period, and liver homogenates were assayed for basal, epinephrine-stimulated, and $\mathrm{NaF}$-stimulated adenyl cyclase activity. Based on $\mathrm{NaF}$-stimulated levels, total adenyl cyclase activity, expressed per milligram of liver protein, was increased after thyroidectomy. Administration of $\mathrm{T}_{3}$ to either hypothyroid or euthyroid rats, however, had no effect on the $\mathrm{NaF}$-stimulated levels. Basal and epinephrine-stimulated enzyme activities were the same in hypothyroid, euthyroid, and hyperthyroid (euthyroid $+\mathrm{T}_{3}$ ) liver homogenates. In contrast, injections of $T_{3}$ in hypothyroid rats increased the activities of basal and epinephrine-stimulated adenyl cyclase. In view of the findings in euthyroid and hyperthyroid liver, it is possible that this effect is transient. In general, no correlation was found between the effects of thyroid hormone on respiration and on adenyl cyclase activity of the rat liver. These results imply that the hepatic thermogenic response to thyroid hormone is not mediated by stimulation of adenyl cyclase activity with the possible exception of the early effects of $T_{3}$ in the athyroid rat.
\end{abstract}

\section{INTRODUCTION}

In previous studies from this laboratory, increased energy utilization for transmembrane-active $\mathrm{Na}^{+}$transport was implicated in the mechanism of thyroid thermogenesis (1). The effect of triiodothyronine $\left(T_{3}\right)^{1}$ on the

Dr. Jones was a recipient of a U. S. Public Health Service Traineeship (HL-05725), Dr. Ismail-Beigi was a recipient of a Bay Area Heart Association Research Fellowship during the course of this work. His present addess is Pahlavi University, Shiraz, Israel.

Received for publication 27 March 1972 and in revised form 27 June 1972.

${ }^{1}$ Abbreviations used in this paper: NaK-ATPase, $\mathrm{Na}^{+}+$ $\mathrm{K}^{+}$-dependent ATPase; $\mathrm{T}_{3}$, triiodothyronine. ouabain-sensitive fraction of respiration correlated with changes in $\mathrm{Na}^{+}+\mathrm{K}^{+}$-dependent adenosine triphosphatase (NaK-ATPase) in rat liver, kidney, and brain (2). The effect of $\mathrm{T}_{3}$ on NaK-ATPase activity was selective in that the activities of $\mathrm{Mg}$-ATPase and $5^{\prime}$-nucleotidase, two other plasma membrane enzymes, were not significantly altered by administration of $\mathrm{T}_{3}$ to euthyroid or to hypothyroid rats. Adenyl cyclase, a plasma membrane enzyme involved in many hormone-regulated systems, however, was not assayed in these earlier studies.

Krishna, Hynie, and Brodie (3) attributed the increased lipolysis in adipose tissue of thyroxine-treated euthyroid rats to increased activity of epinephrine-stimulated adenyl cyclase. It is probable that thyroid hormone does not stimulate adenyl cyclase activity in all target tissues, since a number of studies showed no change in myocardial adenyl cyclase activity or of cyclic AMP content of hyperthyroid animals (4-7). Thyroid hormone, however, may alter the sensitivity of adenyl cyclase to stimulation since Levey, Skelton, and Epstein (5) found depressed levels of epinephrine and fluoride-stimulated enzyme activity in hypothyroid, rat heart homogenates.

The present study was intended to assess the effects of thyroid status on basal, and epinephrine and fluoridestimulated hepatic adenyl cyclase activity with respect to thermogenesis.

\section{METHODS}

Preparation of animals. Male, Sprague Dawley rats (170$250 \mathrm{~g}$ ) fed on Purina chow diet (Ralston Purina Co., St. Louis, Mo.) ad lib. were used in all experiments. The hypothyroid rats were thyroidectomized 3-5 wk before use and maintained on the same diets as the euthyroid group. A few rats from whom the parathyroid glands had inadvertently been removed developed tetany and died within 2-3 days. Other animals exhibiting irritability were not used. Serum protein-bound iodine levels on seven euthyroid and nine hypothyroid rats were determined (Bioscience Laboratories, Van Nuys, Calif.) with the following results: euthyroid = $4.1 \pm 0.2 \mu \mathrm{g} / 100 \mathrm{ml}$, thyroidectomized $=1.4 \pm 0.2 \mu \mathrm{g} / 100 \mathrm{ml}$. 
Pairs of euthyroid rats were injected either with $\mathrm{T}_{\mathbf{3}}$ (Sigma Chemical Co., St. Louis, Mo.) dissolved in $5 \times 10^{-4} \mathrm{M} \mathrm{NaOH}$, $50 \mu \mathrm{g} / 100 \mathrm{~g}$ body weight or an equal amount of diluent on 3 alternate days and assayed $24-48 \mathrm{hr}$ after the third injection. The animals were killed by decapitation and 1-g portions of liver $(1 \mathrm{~g})$ were homogenized in $9 \mathrm{ml}$ of $50 \mathrm{~mm}$ Tris, $1 \mathrm{~mm}$ ethylene glycol bis ( $\beta$-aminoethyl ether) $N, N, N^{\prime}, N^{\prime}$-tetraacetic acid (EGTA), $1.3 \mathrm{~mm} \beta$-mercaptoethanol in a Teflonglass homogenizer with five strokes at medium speed. The homogenate was diluted 1:5 with the same buffer solution for use in the assay.

$Q O_{2}$ measurements. Oxygen consumption was determined in liver slices from separate rats in the same group in a Warburg Respirometer as previously described (2).

Adenyl cyclase assay. The enzyme was assayed by a modification of the method of Ramachandran (8). The diluted homogenate $(25 \mu \mathrm{l})$ was added to $30 \mu \mathrm{l}$ of incubation solution with or without epinephrine $(0.01 \mathrm{~mm})$ or $\mathrm{NaF}(10 \mathrm{~mm})$. The tubes were preincubated at $37^{\circ} \mathrm{C}$ for $5 \mathrm{~min}$ and the reaction was started by the addition of ATP- $\alpha-{ }^{32} \mathrm{P}$, ATP, and cyclic AMP in $20 \mu \mathrm{l}$ of $50 \mathrm{~mm}$ tris buffer. The final incubation mixtures contained: $30-100 \mu \mathrm{g}$ of homogenate protein, $2 \mu \mathrm{Ci}$ of $\mathrm{ATP}-\alpha-{ }^{32} \mathrm{P}(\sim 2 \mathrm{Ci} / \mathrm{mm}$, New England Nuclear, Boston, Mass.), $2 \mathrm{~mm}$ ATP, $3.4 \mathrm{~mm} \mathrm{MgCl}_{2}$, $0.25 \mathrm{~mm} \mathrm{KHCO}_{3}, 0.08 \%$ bovine serum albumin, $0.33 \mathrm{~mm}$ EGTA, $2 \mathrm{~mm}$ cyclic $3^{\prime}, 5^{\prime}$-AMP, $17 \mu \mathrm{g}$ of creatinine kinase, $30 \mu \mathrm{g}$ creatine $\mathrm{PO}_{4}, 50 \mathrm{~mm}$ Tris $-\mathrm{HCl}, \mathrm{pH}=7.5$, in a final volume of $75 \mu \mathrm{l}$. The reaction was stopped in $15 \mathrm{~min}$ by the addition of $200 \mu \mathrm{l}$ of $50 \mathrm{~mm}$ Tris- $\mathrm{HCl}$ buffer, $\mathrm{pH}=7.4$, containing $14 \mathrm{~mm}$ cyclic AMP and $0.16 \mu \mathrm{Ci}$ cyclic $\mathrm{AMP}-{ }^{3} \mathrm{H}$, and boiling for $3 \mathrm{~min}$. After the tubes had cooled, the entire contents was pipetted onto a Pasteur pipet column (0.5 $\times 4.0 \mathrm{~cm}$ ) composed of $\mathrm{PbSO}_{4},{ }^{2} 2.0 \mathrm{~cm}$ below, and neutral alumina, activity I (Brinkman Instruments, Inc., Westbury, N. Y.) $2.0 \mathrm{~cm}$ above. The columns were washed with 2.8 $\mathrm{ml}$ of $10 \mathrm{~mm}$ Tris- $\mathrm{HCl}$ buffer, $\mathrm{pH} 7.4$ and the effluent, containing $80-90 \%$ of the cyclic AMP, was collected in counting vials. $15 \mathrm{ml}$ of Bray's dioxane counting solution ${ }^{3}$ was then added to the vials and the samples were assayed for ${ }^{3} \mathrm{H}$ and ${ }^{32} \mathrm{P}$ content in a liquid scintillation spectrometer (Mark I, Nuclear-Chicago Corp., Des Plaines, Ill.). The assays were corrected for quenching with an external standard. The blank values were determined by adding ATP- $\alpha-$ ${ }^{32} \mathrm{P}$ to incubation mixtures devoid of the labeled nucleotide at the end of the incubation period just before boiling. To calculate the per cent of cyclic AMP in the column effluents, the same quantity of ${ }^{3} \mathrm{H}$ as in the incubation mixtures, devoid of ATP $-\alpha^{32} \mathrm{P}$, was processed in parallel with the assay tubes, diluted $1: 5$, and $250 \mu \mathrm{l}$ was placed directly in counting vials and the $100 \%$ value was computed from these counting rates. Similar samples were also assayed for total ${ }^{32} \mathrm{P}$ content in the absence of cyclic $\mathrm{AMP}^{-3} \mathrm{H}$. The protein contents were determined by the method of Lowry, Rosebrough, Farr and Randall (9).

\footnotetext{
${ }^{2}$ Commercial $\mathrm{PbSO}_{4}$ was found to be unsatisfactory for use in these columns. Accordingly $\mathrm{PbSO}_{4}$ was prepared from reagent grade $\mathrm{ZnSO} 4$ and $\mathrm{PbNO}_{3}$ in stoichiometric proportions and cleaned by repeated washings with distilled $\mathrm{H}_{2} \mathrm{O}$.

${ }^{3}$ The scintillation solution consisted of $30 \mathrm{~g}, 2,5$-dipheny1oxazole (PPO), 1.5 g 1,4-bis[2-(4-methyl-5-phenyloxazoly1)] benzene, $240 \mathrm{~g}$ naphthalene in $429 \mathrm{ml}$ xylene, $1284 \mathrm{ml} p$-dioxane, and $1284 \mathrm{ml}$ ethylene glycol monomethyl ether.
}

TABLE I

$\mathrm{QO}_{2}$ of Rat Liver Slices from Hypothyroid and Euthyroid Rats: Effect of $T_{3}$

\begin{tabular}{|c|c|c|c|c|c|}
\hline Thyroid states & $\begin{array}{l}\text { Pairs } \\
\text { of } \\
\text { rats }\end{array}$ & $\begin{array}{c}(1) \\
\mathrm{QO}_{2}\end{array}$ & $\begin{array}{c}(2) \\
\mathrm{QO}_{2}\end{array}$ & $\begin{array}{l}\text { Pairs } \\
\text { of } \\
\text { rats }\end{array}$ & $\begin{array}{c}(3) \\
\mathrm{QO}_{2}\end{array}$ \\
\hline & & $\begin{array}{l}\mu l / m g d r y \\
w t . p e r ~ h r\end{array}$ & $\begin{array}{l}\mu l / m g \\
\text { protein } \\
\text { per } h r\end{array}$ & & $\begin{array}{c}m g \text { protein/ } \\
m g d r y \\
w t . \times 100\end{array}$ \\
\hline Hypothyroid & 10 & $5.6 \pm 0.2$ & $10.5 \pm 0.4$ & 6 & $53.3 \pm 2.8$ \\
\hline Hypothyroid $+\mathrm{T}_{3}$ & 10 & $11.4 \pm 0.6$ & $20.1 \pm 1.1$ & 6 & $56.6 \pm 2.6$ \\
\hline Euthyroid & 14 & $8.3 \pm 0.3$ & $12.8 \pm 0.5$ & 15 & $65.0 \pm 4.2$ \\
\hline Euthyroid $+T_{3}$ & 14 & $12.4 \pm 0.4$ & $18.0 \pm 0.6$ & 15 & $68.8 \pm 3.1$ \\
\hline
\end{tabular}

The $\mathrm{QO}_{2}$ of liver slices from euthyroid and hypothyroid rats with or without previous $T_{3}$ treatment was measured as described in the text (column 1). In parallel experiments, ratios of milligrams protein/milligram dry weight were determined on separate rats (column 3), were used to express $\mathrm{QO}_{2}$ as a function of protein concentration (column 2).

\section{RESULTS}

$Q O$ s in rat liver. The $\mathrm{QO}_{2}$ of slices of euthyroid and hypothyroid rat liver expressed per milligrams dry weight are presented in Table $\mathrm{I}$, and shows a significant increase in $\mathrm{QO}_{2}$ after $\mathrm{T}_{3}$ treatment. Earlier studies (12, 13) showed that on this treatment schedule, the $\mathrm{QO}_{2}$ reaches a steady level by $48 \mathrm{hr}$. Thermogenesis of this magnitude should be sufficient to determine whether effects of thyroid hormone on adenyl cyclase activity are involved in this response. The ratio of protein concentration to dry weight increases with $T_{3}$ treatment (Table $\mathrm{I}$ ) and this ratio has been used to express $\mathrm{QO}_{2}$ as a function of milligrams protein to serve as a basis for comparison with enzyme data.

Adenyl cyclase activity. The effects of $\mathrm{T}_{3}$ on rat liver adenyl cyclase activity are summarized in Table II. In hypothyroid rats the hormone had no effect on $\mathrm{NaF}$ stimulated activity which suggests that $T_{3}$ did not alter maximum enzyme activity. Injection of $\mathrm{T}_{3}$, however, increased basal activity by $49 \%(P<0.01)$ and epinephrine-stimulated activity by $56 \%(P<0.01)$. The absolute increase in activity produced by epinephrine (E-B) was $66 \%$ greater after $\mathrm{T}_{3}(P<0.05)$. A comparison of the fractional increase in activity produced by epinephrine $(E / B)$ reveals a twofold increase in all four groups. Thus, $\mathrm{T}_{3}$ increased basal and epinephrine-sensitive activity proportionately.

In euthyroid rats, $\mathrm{T}_{3}$ had no significant effect on basal, epinephrine-, or $\mathrm{NaF}$-stimulated activity. It is of interest that total activity in the presence of $\mathrm{NaF}$ was considerably higher in the hypothyroid than in the euthyroid rat liver regardless of whether or not $T_{3}$ was given. 
TABLE II

The Effect of $T_{3}$ Treatment In Vivo on Adenyl Cyclase Activity of Rat Liver

\begin{tabular}{|c|c|c|c|c|c|c|}
\hline \multirow[b]{2}{*}{ Thyroid status } & \multirow{2}{*}{$\begin{array}{l}\text { Rat } \\
\text { No. }\end{array}$} & \multicolumn{5}{|c|}{ Adenyl cyclase activity (pmoles cyclic AMP formed/mg protein per $15 \mathrm{~min}$ ) } \\
\hline & & Basal & +Epinephrine & $+\mathrm{NaF}$ & $(\mathrm{E}-\mathrm{B})$ & $(\mathrm{E} / \mathrm{B})$ \\
\hline Hypothyroid & 11 & $34.1 \pm 3.5$ & $68.9 \pm 5.7$ & $355 \pm 20$ & $34.6 \pm 4.1$ & $2.09 \pm 0.14$ \\
\hline Hypothyroid $+\mathrm{T}_{3}$ & 11 & $50.9 \pm 5.2^{*}$ & $107.8 \pm 11.8^{*}$ & $365 \pm 23$ & $57.6 \pm 9.5^{*}$ & $2.23 \pm 0.24$ \\
\hline Euthyroid & 11 & $30.5 \pm 3.1$ & $69.7 \pm 6.2$ & $246 \pm 15$ & $39.2 \pm 4.0$ & $2.34 \pm 0.15$ \\
\hline Euthyroid $+\mathrm{T}_{3}$ & 10 & $35.7 \pm 6.8$ & $68.5 \pm 12.9$ & $239 \pm 32$ & $32.8 \pm 6.6$ & $1.94 \pm 0.12$ \\
\hline
\end{tabular}

Data are expressed as mean \pm 1 SEM.

* Denotes statistically significant differences $(P<0.05)$ between values in treated vs. untreated rats in the same group; (E-B) denotes the paired differences in activity of the epinephrine (E) and basal (B) states; $(E / B)$ denotes the ratio of epinephrine $(E)$ to basal $(B)$ states.

\section{DISCUSSION}

Sutherland, Rall, and Menon (10) proposed that $\mathrm{NaF}$ stimulated activity provides a measure of the total adenyl cyclase (core enzyme) content of a tissue. $\mathrm{NaF}$-stimulated total adenyl cyclase activity was higher in initially hypothyroid than in euthyroid rat liver (Table II). These changes are the converse of those reported by Levey, Skelton, and Epstein (11) of decreased total adenyl cyclase activity in hypothyroid cat myocardium. Both in our studies and those of Levey et al. (11), enzyme activity is expressed per milligrams of protein in the cell fraction. It is possible that divergent changes in average protein content of these tissues could explain the observed differences. The failure of a short course of treatment with $\mathrm{T}_{3}$ to restore $\mathrm{NaF}$-stimulated activity to that of the euthyroid state may indicate a slow response mechanism. Alternatively, this increase in apparent enzyme activity after thyroidectomy might be a result of effects other than that of circulating levels of $\mathrm{T}_{3}$ or thyroxine, e.g., extrathyroidal effects of excess thyroid-stimulating hormone (TSH), of calcitonin deprivation, or of subtle hypoparathyroidism. In any case, there was no correlation between total adenyl cyclase activity and the metabolic response to the hormone (see Tables I and II).

Basal and epinephrine-stimulated adenyl cyclase activity may be the relevant quantities with respect to thyroidal influences in vivo. A comparison of these activities reveals no differences in the hypothyroid, euthyroid, and hyperthyroid (euthyroid $+\mathrm{T}_{3}$ ) livers (Table II). These results eliminate any simple and direct correlation between effects on adenyl cyclase activity and on respiration (see Tables I and II). This interpretation is in accord with the inference that changes in adenyl cyclase activity do not mediate the thermogenic action of thyroid hormone in the mammalian heart (4-6). The response of adipose tissue to thyroid hormone, however, apparently involves effects on adenyl cyclase activity or on catecholamine stimulation of the enzyme (3). This raises the question of the physiological implications of the finding of a significant increase in basal and epinephrine-stimulated adenyl cyclase activity of liver in $\mathrm{T}_{3}$ treated, thyroidectomized rats (Table II). The lack of correlation between the effects of $T_{8}$ on adenyl cyclase activity and $\mathrm{QO}_{2}$ in euthyroid rats, however, casts doubt on the role of changes in adenyl cyclase activity in the thermogenic response of thyroidectomized animals. Additional information is needed to resolve this question.

In general, our results support the earlier suggestions that among the population of plasma membrane-bound enzymes, thyroid hormones selectively increase the activity of NaK-ATPase.

\section{ACKNOWLEDGMENTS}

We wish to thank Mrs. Vivien Ho for valuable technical assistance and Mr. James Nelson for performing the thyroidectomies.

Financial support for this study was supported by U. S. Public Health Service grant HL-0-6285.

\section{REFERENCES}

1. Ismail-Beigi, F., and I. S. Edelman. 1970. Mechanism of thyroid calorigenesis : role of active sodium transport. Proc. Natl. Acad. U. S. A. 67: 1071.

2. Ismail-Beigi, F., and I. S. Edelman. 1971. The mechanism of the calorigenic action of thyroid hormone. Stimulation of $\mathrm{Na}^{+}+\mathrm{K}^{+}$-activated adenosinetriphosphatase activity. J. Gen. Physiol. 57: 710 .

3. Krishna, G., S. Hynie, and B. B. Brodie. 1968. Effects of thyroid hormones on adenyl cyclase in adipose tissue and on free fatty acid mobilization. Proc. Natl. Acad. Sci. U.S. A. $59: 884$

4. Sobel, B. E., P. J. Dempsey, and T. Cooper. 1959. Normal myocardial adenyl cyclase activity in hyperthyroid cats. Proc. Soc. Exp. Biol. Med. 132: 6.

5. Levey, G. S., C. L. Skelton, and S. E. Epstein. 1969. Influence of hyperthyroidism on the effects of norepinephrine on myocardial adenyl cyclase activity and contractile state. Endocrinology. 85: 1004.

6. McNeill, J. H., L. D. Muschek, and T. M. Brody. 
1969. The effect of triiodothyronine on cyclic AMP, phosphorylase, and adenyl cyclase in rat heart. $C a n . J$. Physiol. Pharmacol. 47 : 913.

7. Frazer, A., M. E. Hess, and J. Shanfeld. 1969. The effects of thyroxine on rat heart adenosine $3^{\prime}, 5^{\prime}$-monophosphate, phosphorylase b kinase and phosphorylase a activity. J. Pharmacol. Exp. Ther. 170: 10.

8. Ramachandran, J. 1971. A new simple method for separation of adenosine $3^{\prime}, 5^{\prime}$-cyclic monophosphate from other nucleotides and its use in the assay of adenyl cyclase. Anal. Biochem. 43 : 227.

9. Lowry, O. H., N. J. Rosebrough, A. L. Farr, and R. J. Randall. 1951. Protein measurement with the Folin phenol reagent. J. Biol. Chem. $193: 265$.
10. Sutherland, E. W., T. W. Rall, and T. Menon. 1962. Adenyl cyclase. I. Distribution, preparation, and properties. J. Biol. Chem. $237: 1220$.

11. Levey, G. S., C. L. Skelton, and S. E. Epstein. 1969. Decreased myocardial adenyl cyclase activity in hypothyroidism. J. Clin. Invest. 48 : 2244.

12. Ismail-Beigi, F. 1972. Mechanism of the thermogenic action of thyroid hormones: role of active sodium transport. Doctorate Thesis. University of California, San Francisco.

13. Ismail-Beigi, F., and I. S. Edelman. 1971. Mechanism of thyroid calorigenesis: role of activation of $\mathrm{NaK}$ ATPase. J. Clin. Invest. 50: 47a. (Abstr.) 